\title{
[原䕎部文]
}

\section{連想データベース自己組織化と 自律移動知能ロボットへの応用}

\author{
鈴木 寿* 大西弘之** 有本 卓*
}

連想データベースを自己組織化する簡単で効率の良い方法を提案すると共に，自律移動知能ロボットへ応用す る. システムは, 予め規定された処理部と, 初期状態では空白な記憶部とから成る. 現時点の入力信号に対し, 処理部はこれに似ている過去の入力信号を記憶部から検索し, その関連情報を呼び出す. もし現入力信号の随伴 情報がこの関連情報と一致しなければ, 新たな情報が記憶部のデータベースに付加され，その影響は次回の処理 に反映される.このよう記憶状態と入力信号の双方に依存して,データベースは自己組織化的に成長してゆく. データベース組織化の履歴は入力系列に依存するので, 個々のデータベースは固有な構造を獲得する. もし十分 な長さの入力系列が与兄られると，入力信号と関連情報の対応関係は，入力系列のそれに一致するようになる. 脳に扩淔観的情報処理の概念的ではあるが本質的なモデルを与えているといら点で，また言用的立場からは， 要求された応答をユニバーサルに学習する学習機構へ応用できるという点で, 本システムは意義深い.この学習 機構を利用した廊下用のカメラ方式自律移動ロボットを紹介する。ロボットの頭脳は, プロセッサーi $80286 を$ 搭載したマイクロ計算機によって構成され，ロボットの行動は，C言語に追加設計した小規模のロボット言語を 用いて制御される．良好な実験結果が示される.

\section{1. まえがき}

計画的要素を含む複雑な作業を機械に効率良く行なわ せるには, 専用機器を組み合わせたシステムプラントを 構築すれば良いが，大量生産以外の目的にはシステムの 規模が巨大になり過ぎる場合が多い：これ机わる方法 は，機械汇多様な作業能力と自律移動能力とを持たせ， 機械が目的の場所まで自律的㳊動し所要の作業を行な えるようにすることである. 電子計算機の発達に伴い順 序制御が容易に実現できるようになった現在, 後者の考 え方に基づき自律移動ロボットに関する研究が積極的に 進められている1. 最新の研究では, 超音波やレーザー 等を用いたセンサ方式移動ロボット2 2, , カメラ方式移動 ロボッド (8), また移動計画に関する各種の手法9,10)など が報告されている．著者らもまた，こうした現状を背景 に, 機械知能 (machine intelligence (MI)) を探究する 立場から自律移動ロボットへのアプローチを試みている。

自律移動ロボットは(1)位置同定, 障害物回避移動, 対 外操作と呼ばれる三つの機能, (2)それらを統括・制御す

原稿受付 1987 年 6 月 1 日

* 大阪大学基礎工学部

** グローリー工業株式会社
る上位制御プログラム，お上び(3)その他の補助的機能と から構成される.この構四は, 従来提唱されてきたすべ ての自律移動ロボットシステムに厳密に当てはまるわけ ではないが，どの方式もほぼ同様なアーキテクチャを持 つ.さて，(1)において位置同定とは，ロボットが現在居 る座標を周囲の風景から同定する機能である，位置同定 を行ならには变位量を積分する方式も考えられるが, 長 時間・長距離移動のとき誤差が蓄積し許容範囲を越える 危険があるので,ここでは採用しない，障害物回避移動 とは, 現在居る座標から指定された別の座標まで，不測 障害物を検知し回避しつつ移動する機能である. 対外操 作とは, 目的地へ到達した後に, 所要の作業を遂行する 機能である.また(2)の上位制御プログラムとは, 個々の 作業内容に応じて, (1)機能の適用を指令する手続きで ある. 以上の機能はいずれの用途の自律移動ロボットに も共通して必要であるが，それ以外の対外操作および副 次的機能は，目的に応じて適宜その仕様が变更される. 本論文では, 実用的な自律移動ロボット実現へ向けての 第一ステップとして, 位置同定, 障害物回避移動, およ び基本的な上位制御プログラムから成る最小システムを 実構成した旨を報告する。

自律移動ロボットの運用環境は室内, 廊下, 道路, 荒 
地，特種区域などいろいろ考えられるが，特に廊下移動 に関しては走行系を殊さら強化する必要が無く，しかも 壁を障害物とみなすことにより自然のがイドラインが与 えられ簡単な移動戦略で済むので，初期段階の研究対象 として好適である.屋内移動ロボットについては既に， ガイドラインとして光学または磁気テープを人為設置し， 超音波を利用して進路上に障害物を感知したとき自動停 止する方式が普及している，だが超音波からは点情報し か得られないので，その情報のみに頼って障害物を効果 的に回避することは難しい，そこで，本研究では将来の 自律移動ロボットに対する高度なニーズを考應し, 豊富 な領域情報を含んでいるカメラ画像を利用して超音波方 式よりも適確に移動できる廊下移動ロボットを開発する こととした (Fig. 1). 試験対象は著者らの研究室が在る 建物内の廊下であるが，そこにはエアコン用パイプ，半 固定化された消火設備，ロッカー，またしばしば位置が 変わる灰皿受け，ガスボンへ，箱といった障害物があり， 比較的劣覀な環境にある.

本論文の目的は第一に, 学習能力を要する機械系の設 計に有効な学習機構の一構成原理, 即ち連想データベー ス自己組織化を提案し，第二にこれを応用したカメラ方 式自律移動ロボットの製作報告を通じて, MI 分野にお ける基礎技術確立の一端への寄与を目指すことにある.

従ってロボットの機構関係の説明に終始することは避け, できる限り方法論の本質を述べることに主眼を置く。こ の方針に従い第 2 章で学習機構に関する背景と理論面と を論じ，第 3 章では自律移動ロボットへの具体的な応用
法を展開する。

\section{2. 連想データベース自己組借化法の提案}

\section{1 学習の意军と方式}

自律移動ロボットは地図上で現在座標から目的座標へ の適切な経路（即ち，建物内のいずれの通路セクション を経由すべきか）を高次判断した後，位置同定と障害物 回避移動とを併用しながら計画経路に沿って目的座標ま で進行する．この移動戦略を実現するために， ロボット に小型電子計算機を搭載し, 個々の場面に応じた仕事の 綿密なプログラムを準備しておくことにより複雑な環境 への対処能力を賦与しょうとする論理志向の方法論が主 流である ${ }^{1 \sim 01}$. だが一方では，この方法は，論理に支配 される高次情報処理, 即ち大局的な移動計画などには有 効である反面，論理的といらよりむしろ直観的応答に近 い位置同定や障害物回避移動などには必ずしも適さない 事実が知られつつある.

この問題に対する一つの解決策はロボットに直観的応 答のパターンを学習させることである．良く知られてい る学習機構には, 人工知能におけるように学習用のモデ ルに従って知識を獲得する方式 ${ }^{11,12)}$ ， あるいはニューラ ルネットワーク 13 15) のように記憶のポテンシャル場を 形成する方式等がある。これらを活用すれば，例えば， 障害物の配置状況に対する経路生成の有限次元モデルの 下で，適切な移動経路が選択されるように俰数ファクタ 一の值を自動調整する機構を構成し得る.これに対し本 論文では新たに, 自己組織化を行なら学習機構を提案す

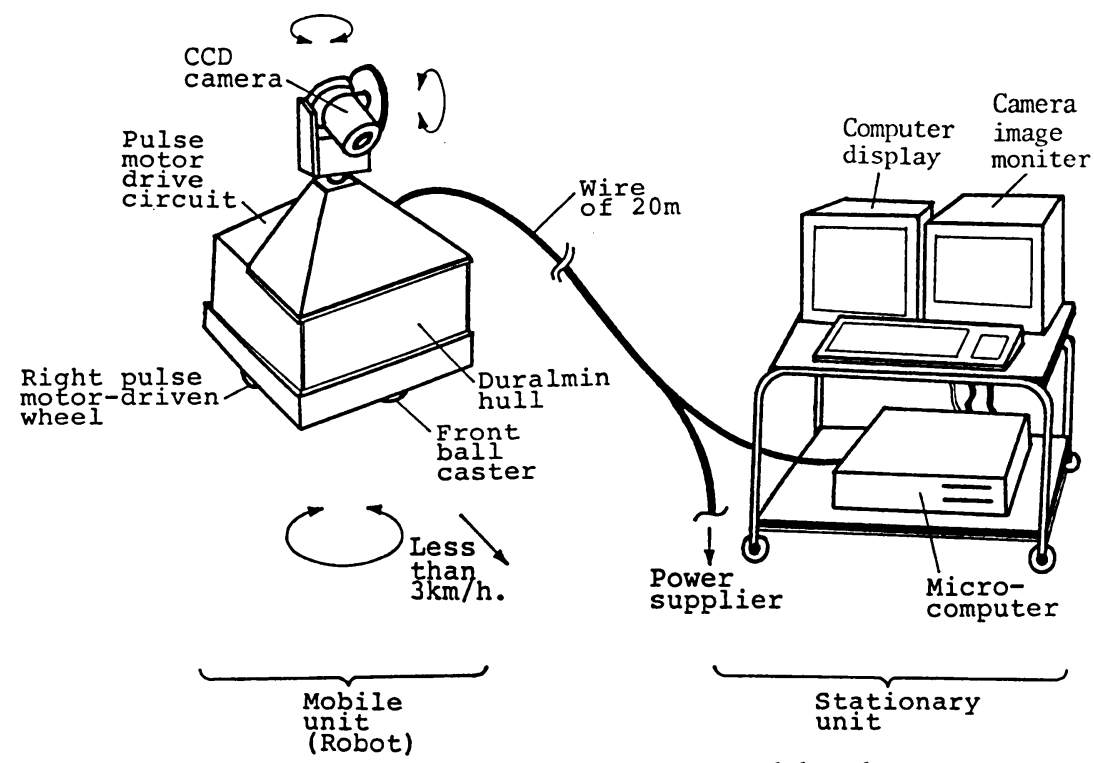

Fig. 1 Configuration of autonomous mobile robot 
る.（自己組織化といら術語自体は従来の方式において もしばしば用いられるが，本論文では固有の意味で用い る.)この方式は, 次節以降で明らかにされるように, カ メラ画像などの標本系列中に潜む情報論的構造を, 先験 的に与えられた情報処理規則に基づき, 順次に次元を上 げながら抽出してゆく. それ故, 従来方式の学習機構と 異なりモデル設定の不備に起因する解析上の歪みは残ら ず，種々の応用に際し都合の良い性質をもたらすことが 期待される.

\section{2 連想データベースの自己組織化アルゴリズム}

自己組織化を行なら学習機構は, 固定化された処理部 と可塑性を備えた記憶部とから成る. 学習用の標本を処 理部で分析した結果, 必要ならば記憶部の内容を更新し, 更に記憶内容は再㷌的に次回の処理過程に影響を及ぼす. そのような自己組織化の手順は種々考え得るが，ここで は工学的意味が明瞭な次の一つを定義する：入力信号を $x \in X$, 各々の $x$ と一意に対応付けられる関連情報を $y$ $\in Y$ と記す.ここに $X$ および $Y$ はそれぞれ，ある有限 または無限集合を表わす. 処理部は, 二個の入力信号を 引数とし非負実数値をとる関数 $d$ のうち,

$$
\forall\left(y, y^{\prime}\right) \in Y \times Y, y \neq y^{\prime} \Longrightarrow d\left(x, x^{\prime}\right)>0
$$

を満たすある $d$ によって規定される一ここに $x, x^{\prime}$ は, それぞれ関連情報 $y, y^{\prime}$ に対応する入力信号を表わす. $d$ は広義の距離関数の一種であるが，このような距離の 概念は Goldfarb ${ }^{16)}$ が詳しい（後に第 3 章で, 大まかに 言って, カメラ画像を $x$; 二枚のカメラ画像間に定義さ れる非類似度を $d$; 更に位置同定の用途では画像収録時 点のロボットの座標を $y$, また障害物回避移動の用途で は, 画像 $x$ に対して選択すべき移動経路を $y$ とおくこと
になる.) さて, $x$ と $y$ との対応関係を標本系列から学習 し再生するアルゴリズムは次の通りである.

【アルゴリズムA】 $X \times Y$ から無作為に選ばれた 標本 $(x, y)$ の系列 $\left\{\left(x_{t}, y_{t}\right) ; t=1,2, \cdots\right\}$ に対し, 次の手順 により記憶部を木状データベースの形態で組織化する：

(1) (初期設定) $x[$ 根 $]=x_{1}, y[$ 根 $]=y_{1}$ とおき, 根の みから成る木を設定する一ここに $x[\cdot], y[\cdot]$ は, 各節 に割り当てられた記憶用変数を表わす. また $t=1$ とお $<$.

(2) $t$ を1だけ增やす. 節を表わすポインター $n$ を根 にリセットした後, $n$ が葉即ち末端節へ到達するまで以 下を繰り返す： $n$ の子節を $n_{L}, n_{R}$ とおくとき，

$$
d\left(x_{t}, x\left[n_{L}\right]\right) \leqq d\left(x_{t}, x\left[n_{R}\right]\right)
$$

ならば $n=n_{L}$, それ以外ならば $n=n_{R}$ とおく.

(3) $y[n]=y_{t}$ ならば(2)へ戻り, それ以外ならば, $n$ た 続く新たな子節 $n_{L}, n_{R}$ を増設し

$$
\begin{aligned}
& x\left[n_{L}\right]=x[n], y\left[n_{L}\right]=y[n], \\
& x\left[n_{R}\right]=x_{t}, y\left[n_{R}\right]=y_{t}
\end{aligned}
$$

とおいた後(2)へ戻る.

例えば, 標本系列

$\left(x_{1}, y\right),\left(x_{2}, y^{\prime}\right),\left(x_{3}, y^{\prime}\right),\left(x_{4}, y\right),\left(x_{5}, y^{\prime}\right),\left(x_{6}, y^{\prime}\right), \cdots$ が与えられたとき，次の手順が実行される (Fig. 2).

時刻 $1:\left(x_{1}, y\right)$ を根の位㯰に記録する.

時刻 $2:\left(x_{1}, y\right),\left(x_{2}, y^{\prime}\right)$ を葉の位置に記録する. この 時点で Fig. 2 における木は第 1 レベルまで成長する.

時刻 3 : ポインターを根に直く. $x_{3}$ と，それぞれの子節 に記録されている入力信号との距離 $d\left(x_{3}, x_{1}\right), d\left(x_{3}, x_{2}\right)$ を計算し大小比較を行なう.もし $d\left(x_{3}, x_{1}\right)<d\left(x_{2}, x_{1}\right)$ の とき, $x_{1}$ が記録されている子節へポインターを移動する.

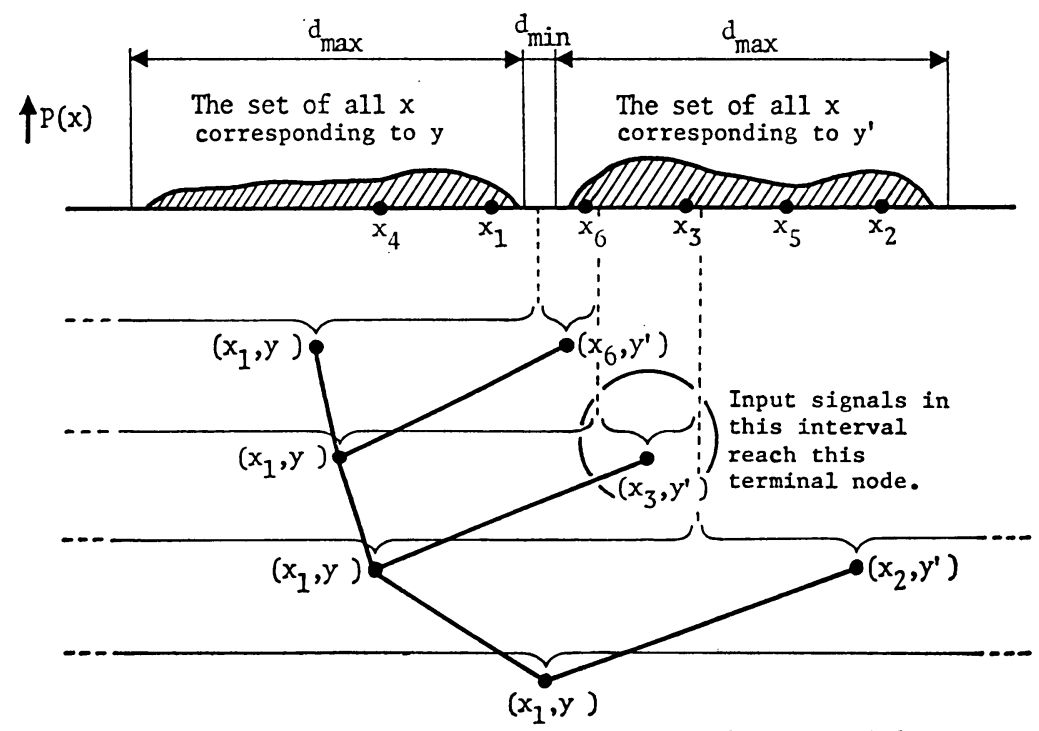

Fig. 2 An example of data-base organization in one-dimensional distance space 
このように到達先の関連情報 $y^{\prime}$ が真の関連情報 $y$ と異 なる場合，枝を延長しその先端に $\left(x_{1}, y\right),\left(x_{3}, y^{\prime}\right)$ を記 録する.この時点で木の左側が第 2 レベルまで成長する. 時刻 $4:$ ポインターを根に膡く. $x_{4}$ と, それぞれの子節 に記録されている入力信号との距離 $d\left(x_{4}, x_{1}\right), d\left(x_{4}, x_{2}\right)$ を計算し大小比較を行な 5 .もし $d\left(x_{4}, x_{1}\right)<d\left(x_{4}, x_{2}\right)$ の とき, $x_{1}$ が記録されている子節へポインターを移動する. ここでもら一段階，それぞれの子節との間で距離比較を 行ない, るし $d\left(x_{4}, x_{1}\right)<d\left(x_{4}, x_{3}\right)$ のとき, $x_{1}$ が記録され ている子節へポインターを移動する.こうして到達した 葉に記録されている関連情報 $y$ が真の関連情報 $y$ と一致 する場合は木を更新しない：この時点で木の左側は第 2 レベルに保たれたままである.

時刻 5 : 以上と同様な手順で，現入力信号 $x_{5}$ に似てい る入力信号を探索する. もし $x_{2}$ が記録されている葉に 到達した場合, 正しい関連情報 $y^{\prime}$ が呼び出されるので 木を更新しない。

時刻 6 : もし現入力信号 $x_{6} か ゙ x_{1}$ の葉に到達した場合, 誤った関連情報 $y$ が呼び出されるので，木を更新する. この時点で木は第 3 レベルまで成長する.

（もっと具体的には，第 3 章でこのアルゴリズムは，現 在のカメラ画像に似ている過去のカメラ画像をデータべ 一スより探索し，それに随伴して記録されている位置情 報や経路情報を呼び出すと共に, エラーが無視し得るよ らになるまでデータベースの更新を繰り返すといら作業 を行ならことになる.）

学習手順は以上の通りであるが，これは任意の時刻で 終了してよく，引き続き再開してもよい，学習終了後ま たは中断中は, 任意の入力信号に対し, 到達した葉に記 録されている関連情報をそのまま出力する.

学習の初期段階では総節数は標本数にほほ比例して增 大するが，学習が進行するにつれ成長速度が漸近的に衰 え, やがて停止する. 入力信号と, 到達した葉に記録さ れている関連情報との対応関係が，徐々に標本系列のそ れに近づいてゆくことは直観的に明らかであろう。

ある視点からは， $d$ および記憶内容はそれぞれ，先験 知識に基つくく推論規則, および後験的に獲得された知識 に対応しており、アルゴリズム $\mathrm{A}$ とは標本に応して知識 を修正する手続きであると見なせる。をた別の視点から は， $d$ および記憶内容はそれぞれ信号解析の基底および その解析結果の記録歴に対応しており, 学習対象の構造 の複雑さに応じて基底の次元を自動的に増大する解析手 続きとも見なせる。このようにアルゴリズム A は, 知識 管理の手法に共通じだソフトウェア構成の一つの枠組み を与えており, 沉用性が高い。

アルゴリズムAのも5一つの重要性は, 記憶領域全体
を探索することなく記憶の再生や更新ができるよらに木 状データベースを構成している点にある，木状データべ 一スに関する研究は古くから行なわれているが，その多 くは，十分な個数の標本が与えられた前提下で，葉の平 均探索時間が最小化されるよらに木を組織化するボトム フップ的な記憶の管理形態を扱っている ${ }^{17)}$. 一方提案し た学習機構は, 標本がまだ十分に収集されていなくとも 将来を見越してトップダウン的に記憶構造を整理してゆ く管理形態をとっている．このように引数の内容に依存 してアドレスが決まる形態は，連想データベース，ある いはほぼ同義語で連想記憶系と呼ばれて17),データベース の分野において重要な研究課題としてしばしば採り上げ られる.ささて, 各々の葉の探索時間の最覀値は木の最大 レベル数によって押えられ，更に後者は節数の関数とし て表わされる.よく知られているよらに，最適木におけ る探索時間の最悪値の漸近的評価は, 総節数の対数関数 のオーダーとなる ${ }^{18)}$. 一方 2.3 節で示されるように, あ る複雑さの学習対象の類に対し、アルゴリズムAによっ て構筑される木上での探索時間の最悪値の漸近的評価も また, 最適木の場合と同じく総節数の対数関数オーダー を達成する、これは,データの単なる順次記録とは一線 を画する重要な性質である.

アルゴリズム A の特長はソフトウェアの範囲だけに限 られない。即ち, 仮に入力信号の分岐を担ら“シナプス (synapse，神経接合部)”相当のゲート素子を作製し木 を回路化するならは，学習によってそれらの素子が選択 的に結合された回路網ニニットを実現し得る. そのよう な種々の用途の回路網ユニットを組み合わせることによ って構成され得る情報処理装固は, 新しいタイプの非フ オンノイマン型計算機，またはコネクションマシン151の 一種と見なせ, 生物工学や人工知能などといった人間・ 機械間の境界分野と密接な関連がある.

\section{3 データベースの規模の伻価}

アルゴリズムAによって組織化される木状データベー スのレベル数は計算時間とメモリ容量とに反映されるの で，この量を正確に評価しておく必要がある.レベル数 の上界は次の上らに評価される：Xの分割 $\left\{X_{k} ; k \in K\right\}$ は, 任意の $k$ に対し

$$
\forall\left(x^{\prime}, x^{\prime \prime}\right) \in X_{k} \times X_{k} \Longrightarrow y^{\prime}=y^{\prime \prime}
$$

なるようなある最小個数分割を表わすとする一ここに $y^{\prime}, y^{\prime \prime}$ は，それぞれ入力信号 $x^{\prime}, x^{\prime \prime}$ に対応する関連情 報を表わす. 更に, 個々の $X_{k}$ を囲む最小球の直径の 上界を

$$
d_{\max }=\max _{k \in K} \max _{\left(x^{\prime}, x^{\prime \prime}\right) \in X_{k} \times X_{k}} d\left(x^{\prime}, x^{\prime \prime}\right)
$$

また球どらしの間隙の下界を 


$$
\begin{aligned}
& d_{\mathrm{m} 1 \mathrm{n}}=\min _{\left(k^{\prime}, k^{\prime \prime}\right) \in k_{k^{\prime} \neq k^{\prime \prime}} \in K \times K} \min _{\left(x^{\prime}, x^{\prime \prime}\right) \in X_{k^{\prime}} \times X_{k^{\prime \prime}}} d\left(x^{\prime}, x^{\prime \prime}\right) \\
& K^{\prime}=K^{\prime \prime}
\end{aligned}
$$

と表わし，

$$
r=\left(d_{\max }+d_{\mathrm{min}}\right) / d_{\mathrm{min}}
$$

とおく.

もし，あるm次元ニークリッド空間 $R^{m}$ 上の距離関 数 $d_{m}$ と, ある写像 $\rho: X \rightarrow R^{m}$ とが存在し, かつ任意 の $\left(x^{\prime}, x^{\prime \prime}\right) \in X \times X$ に対し

$$
d\left(x^{\prime}, x^{\prime \prime}\right) / d_{m}\left(\rho\left(x^{\prime}\right), \rho\left(x^{\prime \prime}\right)\right) \leqq a
$$

なる正定数 $a<2$ が存在すれば（即ち $\rho(X)$ が $R^{m}$ 上 でほぼ線形性を有するならば)，任意の時刻においてレ ベル数 lは

$$
l \leqq(|K|-1) \cdot 2^{m-1}\left[\log _{2 / a} r\right]
$$

の範囲にあるーここに $|K|$ は $K$ の要素数を表わす. こ の主張は, 最初 $a=1$ かつ $m=1$ の場合 (Fig. 2) を考 之, 次に $m>1$ の場合, 最後に $a>1$ の場合を考えるこ とにより容易に確かめられる.

以上の結果から知られるように, $K$ の要素数が有限, かつ $r>0$ 即ち球どうしの間腺が僅かでも存在すれば, レベル数は有限である. 更に, $X_{k}$ どうしが良く分離さ

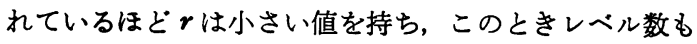
小さい上界によって押えられることがわかる.このよう に, $\boldsymbol{r}$ は学習対象の複雑さを表わす一つの尺度となって いる. 特に, 複雑さが $r=O(|K|)$ の速さで増大すると き, レベル数の上界は $O(\ln |K|)$ となる. この事実は, 直観的に解釈すると，例觉ば同程度の大きさの障害物 が一個ずつ増えるように環境が複雜化してゆくとき，デ ータベースの使用メモり量は指数関数オーダーで增大す るが，葉の探索時間は線形オーダーの増大に留をる事実 を示唆している. ロボットの運用環境の複雑化に伴うデ ータベースの規模の增大は，このように妥当な上界によ って押えられる.

\section{3. 自律移動ロボットへの応用}

\section{1 ロボットの仕様}

Fig.1 を参照しつつ, 自律移動ロボットの主な仕様を 述べる. 固定ニニットはホスト計算機 (NEC PC-9801 VX 4, プロセッサー i 80286) および電源供給器から構成 され, 約 $20 \mathrm{~m}$ の電線を通じて移動ニニットと結合され ている. 以下では慣習に従い移動ニニットを単にロボッ トと呼ぶ. ロボットの制御計画は, ホスト計算機上でC 言語 (Lattice C) とアセンブリ言語 (8086-Assembly) との混用によりプログラムされている.

ロボットはジュラルミン製で，緃・横・高さは共に約 $0.7 \mathrm{~m}$, 重量は約 $30 \mathrm{~kg}$ ある. 底面には一対の 5 相ステ
ップモーター駆動輪および一対のボールキャスターが取 り付けられており, 前後直進とその場回転とができる.

駆動輪の制御は，口ボットに搭載されたステップモータ 一駆動回路を介し，ホスト計算機から制御パルスを伝送 することにより行なら．このとき 3 次曲線状の加速走行 と定速走行とを組み合わせ，ステップモーターが脱調を 起こさないよう配慮している。また口ボット頭部には小 型の CCD カメラ (NEC TI-25A) が二個のステップモ 一ターと共に取り付けられており, 駆動輪と同様ホスト 計算機からの制御パルスに応じて上下・左右首振り運動 を行な5.レンズの焦点距離は $6.5 \mathrm{~mm} て ゙$, 床面からレ ンズ中心までの高さは約 $0.7 \mathrm{~m}$ ある. カメラ画像は, 木 スト計算機内蔵の AD 変換器 (ALTEC ALT 256-4) を 通じ, 視角約 $55 \mathrm{deg}$ に対応する画素数 $256 \times 256$, 輝度 レベル 8 bit の濃淡画像データに変換され， RAM 上へ 一画像当り約 $0.03 \mathrm{sec}$ 以内に直接メモリアク七ス方式 で転送される。また夜間は，ロボット頭部に $100 \mathrm{~W}$ 電 球を取り付けて運用している.

\section{2 位是同定への応用}

原理的にはカメラ画像を入力信号 $x$, ロボットの位置 を関連情報 $y$ と見なし，フルゴリズムAを用いて $x$ と $y$ との対応関係を学習すれば，その後風景から位置を同定 することができる．ところが現実の計算機にはメモリ容 量の制約があるのでテデータベース作成に際しカメラ画 像を縮約して取り扱わなければならず，それに伴う位置 同定の精度の劣化をある程度許容せざるを得ない，従っ て技術的には，位直同定の精度の劣化が許容できなくな る直前の縮約手法を見い出すことが键となる.もし周囲 の風景からロボットの位置を大まかに認識し，正確な位 置を知りたいときに限り，風景中の特徽点に注目し三角 測量の原理などを利用して距離を精密に測定することに すれば，第一段階の位置同定の精度はそれはど高くなく ともよい：さて実験を行なった幅 $2.5 \mathrm{~m}$ の廊下には長 さ $3.6 \mathrm{~m}$ 毎に支柱が突出しており, 隣合ら支柱に挾ま れたブロックを単位として室や扉が割り付けられている (Fig. 3). ある屝から別の扉へ移動するといら行動目的 を想定するとき，第一段階ではカメラの視界を考虑しブ ロック単位の位置同定ができれば十分と考え，実験では $Y=\{1,2, \cdots\}$ とおき,ブロックに命名した番号 $y \in Y$ を 以って関連情報と定めた.

カメラ画像の収録および縮約については，数通りの方 法を試みた後，次のものを採用した：カメラの姿勢を廊 下壁面に対し平行に向くよう初期化した後, 水平面内で $30 \mathrm{deg}$ ずつ回転させ $360 \mathrm{deg}$ に対応する 12 枚の画像を 収録する. 次に, 各々の画像から中心に近い6 本の水平 線を抽出し，それぞれを視角 $30 \mathrm{deg}$ に対応する長さ131 


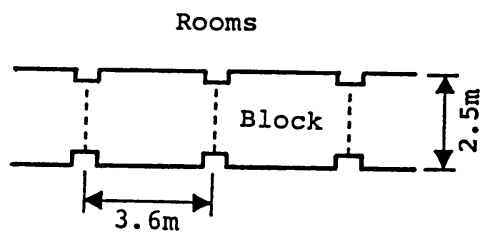

Fig. 3 Passage way

$\operatorname{dot}$ の線画像に切り詰めた後, 12 枚分を結合し垂直高 6 $\operatorname{dot}$, 水平長 $131 \cdot 12=1,572 \operatorname{dot}$ のパノラマ画像を合成 する.これを水平長が 360 dot となるよら間引き縮小し た後, 垂直方向 $6 \operatorname{dot}$ の輝度の平均をとり，1 本の線画 像を得る. 更に水平走査を行ない，輝度变化の激しい点 を黒，それ以外を白とおくことによって二值化し，これ を入力信号 $x$ と定めると共に $X=\{0,1\}^{380}$ と扰く.

任意の二つの縮約画像 $x \in X, x^{\prime} \in X$ 間の非類似度を 測るための $d$ につては，計算時間を考虑に入れ次のも のを採用した (Fig.4). いま $x$ 上のある黒点に注目しこ れを $x^{\prime}$ 上に投射するとき， $x^{\prime}$ 上の最寄りの黒点との幾 何学的距離 $\delta$ を測り， $x$ 上のすべての黒点に関する $\delta$ の 和 Sを求める. 同様に $x$ と $x^{\prime}$ の役割りを交代し $S^{\prime}$ を求 める. $x, x^{\prime}$ の黒点数をそれぞれ $n, n^{\prime}$ と表わすとき $d$ $\left(x, x^{\prime}\right)=1 / 2\left(S / n+S^{\prime} / n^{\prime}\right)$ と定める一ここに約束として, もし $n=0$ または $n^{\prime}=0$ ならば $S / n=0$ または $S^{\prime} / n^{\prime}=0$ と扰いて計算する.

さて，ホスト計算機から送出した駆動輪制御パルスを 計数しておき，誤差が多く蓄積する以前にオペレーター が定期的にリ七ットを掛ければ，口ボットの正確な位置 を常時把握できる．そこで，オペレーターの任意判断に よりロボットを無作為走行させつつ，間欠的にカメラ画 像を収録すると同時にパルス計数値からブロック番号を 算出し，アルゴリズムAを用いて縮約画像 $x$ とブロック 番号 $y$ との対応関係を学習させた (Fig. 5). この作業は 計数値の定期的なりセットを除けば完全に自動化されて おり，いわゆる環境地図の教師なし学習を実現している。

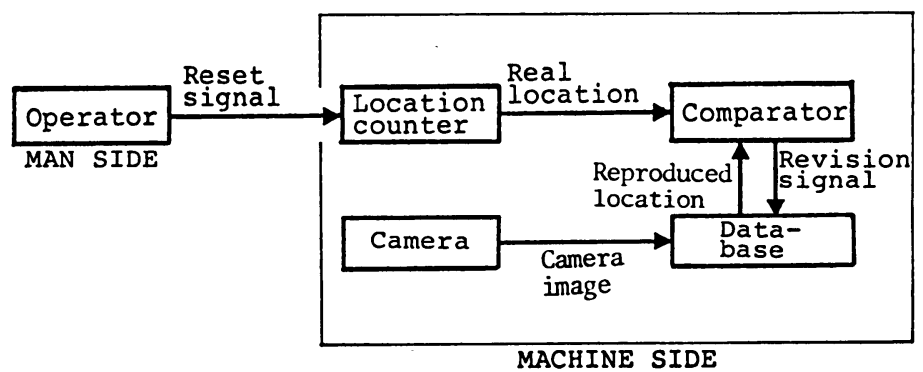

Fig. 5 Learning of environment map without teacher JRSJ Vol5 Na 6

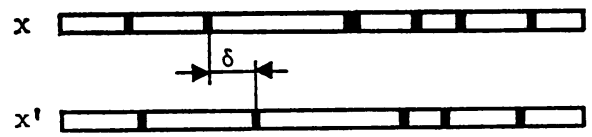

Fig. 4 Calculation of $d$

学習の途中では次のような現象が進行する：いま，あ る座標 $P$ に淤ける縮約画像 $x$ とブロック番号 $y$ とがデータ ベースに記録されたとする. 同ブロック内でそこから少 しだけ移動した座標 $P^{\prime}$ において, 縮約画像 $x^{\prime}$ は先の $x$ と似ているから， $x^{\prime}$ に対しブロック番号 $y$ は正しく再生 されるであろ5，従ってPの周辺では，しばらくの間デ ータベースは更新されないだが隣接するブロックに入 ると，最初に画像を収録した座標 $P^{*}$ 上で不正なブロッ ク番号 yが再生されるので, データベースに新たに縮約 画像 $x^{*}$ とブロック番号 $y^{*}$ とが記録される結果となる。 ところが新たな記録が追加されたことによって，ブロッ ク $y$ と $y^{*}$ の境界付近で $x$ と $x^{*}$ を両極とする類似性の 綱引きによる混乱が生じ,プロック $y$ 内で境界に近い座

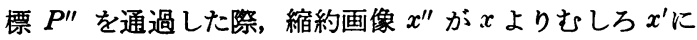
似ていると判定され，不正なブロック番号 $y^{\prime \prime}$ が再生さ れる場合がある.このとき $\left(x^{\prime \prime}, y^{\prime \prime}\right)$ がデータベースに 新しく追加されることとなる．以上のような学習の進行 状況を総括的に眺めると，個々のブロックはほぼ中心付 近で収集された標本に対してはデータベースがほとんど 成長せず，ブロック間の境界付近では，似ている風景間 の相互干涉を淵近的に打ち消すようなデータベースが成 長してゆく現象が観測される.

過去 100 時刻にわたり再生されたブロック番号が 正 解であった回数（即ち, パルス計数値から算出されたブ ロック番号が，データペース上で到達した葉に記録され ているブロック番号と一致した回数）によって再生率を 測る. $18 \mathrm{~m}$ 区間即ち 5 ブロックにおける典型的な再生 率の 100 時刻毎の変遷は Fig. 6 のようになり，400 時 刻で約 84\% に収束した. この時点で節数は 204 となり, レヘル数は 5 から 22 の間に分布していた. なお 3.4 節 に扰けるよらに，ロボットを自律移動さ せるとき，構成されたデータベースを用 いてカメラ画像からブロック番号を同定 するか，実験環境ではこのときの再生率 は何回か日を改めた測定に対し約 $80 \%$ から $84 \%$ の間で変化し，押し並べて学 習時より低い值を示した．その理由は， 室の郝の開閉状態や照明が学習時と異な ることにある. しかしながらたとえ風景 の一部が変化しても，似た風景の探索に それほど強い影響を与えないので，被害 
Fig. 6 Efficiency of learning for location identification

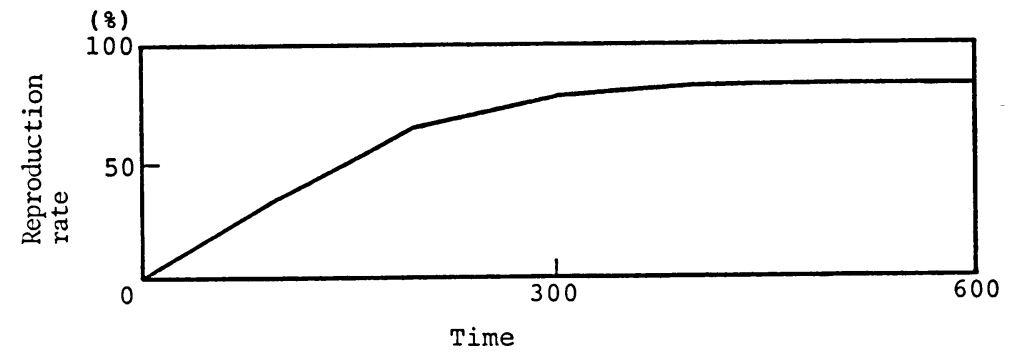

はこの程度に押えられる．実用上は，位置同定を誤る分 は一時刻前に居た位置との比較により棄却できるので, 信頼性について特に問題はない、また，ロボットの移動 範囲が $18 \mathrm{~m}$ を越える場合は, 各区間に対応するデータ ベースを終端で重ね合わせて使用している．また交差点 でも同様にデータベースを重ね合わせて使用している.

再生率が $100 \%$ に到達しない原因は，廊下における風 景が所々で似て拉り, 標本列の $x$ と $y$ との対応関係が一 貫しないことにある，具体的には，再生率の変遷を監視 していると, やがて再生率が上限に収束し, それ以上学 習を続行しても改善されない事態となって現われる.こ のとき学習機構は，一貫していない $x$ と y 対応関係 を記録するべく忠実に枝を延ばしてゆく過程にある.そ れ故, 再生率が上限に達した時点で学習作業を中止する のが望ましい.なお再生率の上限を改善するにはカメラ 画像の縮約の程度を緩めればよいが，先にも述べたよう にメモり容量や $d$ の計算時間に関するハードウェア上の トレードオフがあるので, 現実にはここで行なったよう な妥協が必要である.

\section{3 障要物回避移動人の応用}

原理的にはカメラ画像を入力信号 $x$, 移動経路を関連 情報 $y$ と見なし，アルゴリズムAを用いて $x$ と $y$ との対 応関係を学習すれば，その後場面に応じて移動経路を選 択できるようになる. しかしながらここでもハードウェ フに関する制約が問題となるので，カメラ画像から必要 な情報だけを抽出する工夫を施さなければならない。

入力信号は次のように定めた：カメラを水平面から 28 deg 下方へ向け $256 \times 256$ 画素のカメラ画像を収録し， 低域フィルターに通した後, $32 \times 32$ 画素へ間引き縮小 する. 次に, 画面の底部から上部へ向かって垂直走查し つつ輝度変化の激しい最初の点を探し, 底部からその点 までを白，その上方をすべて黒と置く(Fig. 7).このと き,もしロボットの眼前に障害物がなければ白部分は進 出可能な自由領域を表わしていることになる．実験環境 では床と壁の輝度が明確に異なっており, 壁は確実に障 害物として認識される.こうして得られた二值画像を入 力信号 $x$ と定め, $X=\{0,1\}^{32 \times 32}$ とおく.
また，この画像上に移動経路を描いたものを関連情報 $y$ と定めた (Fig. 7). ここに安全性への配虑と駆動系の 構造上, 移動経路は $\pm 30 \mathrm{deg}$ 以内のその場回転, $1 \mathrm{~m}$ 以 内の前進, $3 \mathrm{~km} / \mathrm{h}$ 以下の 速度指定の三つの 運動指令か ら構成している一即ち Go \& stop 走行をさせる.これ に伴い $Y$ も暗に定められたことになる. 更に, 任意の二 つの入力信号 $x \in X, x^{\prime} \in X$ に対し, 両者の排他的論理 和をとった画像上の黒部分の面積を, 底部から上部へ向 かって垂直高に関する 2 から 1 へわたる比例重みを掛け ながら測り，その結果を $d\left(x, x^{\prime}\right)$ と定めた.

学習は次の手順で行なった：廊下において，元々在る 障害物の他に箱, いす, 消火器, 書類などの様々な障害 物を無作為に配置する．ロボットはカメラ画像を収録し 二値画像 $x$ に変換した後, データベース内で $x$ と似た画 像 $x^{\prime}$ を探索し, それに随伴記録されている画像 $y^{\prime}$ から 抽出した移動経路と, カメラの原画像とを, ホスト計算 機のディスプレイに表示する (Fig. 8). その際, もし再 生した移動経路が自由領域から逸脱しており, 経路通り に進行すれば衝突の危険がある場合には，その旨を警告 表示する.オペレーターは, 計算機によって提案された 移動経路が適切か否かを主観的に判定し，もし不適切な らばマウスを用いて望ましい移動経路を $x$ 上に描き，こ れをデータベースに付加するよう計算機へ指示する. 以 上の手順によって, 標本系列はオペレーターの経路選択 の評価規範を反映する余地を含んだまま，暗黙のうちに 定められることになる.この作業はいわゆる対話形式の 学習を実現しており，オペレーターの満足がゆくまでデ
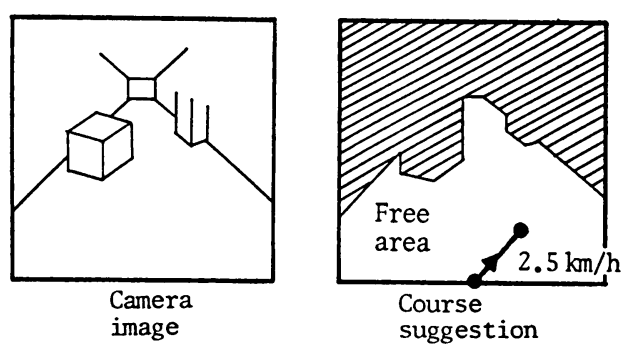

Fig. 7 Extraction of free area and course suggestion 


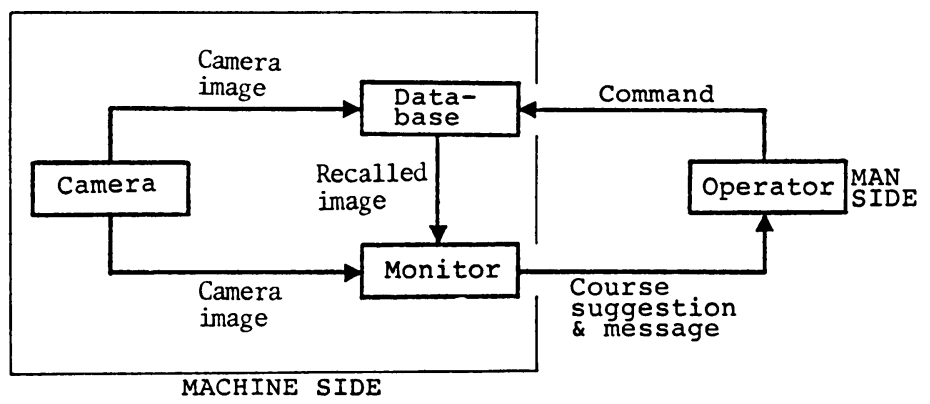

Fig. 8 Learning of courses in interactive form

的な評価規範を設けることなく，オペレ ーターが暗黙のらちに有する評価規範を 忠実にロボットに学習させ，オペレータ 一から見て常に適切に近い移動経路を採 らせることができるので，第二の問題は 自然に解決される。 また（実現したシス テムでは以下の方法は採用していない が）実用化の際には，データベースから 再生された移動経路により衝突の危険が ある場合に限って論理的な移動経路を用 いることにすれば，第一の問題も解決さ

ータベースは繰り返し修正される。

再生率を, 過去 100 時刻にわたりオペレーターが計算 機つ提案する移動経路を受け入れた回数によって定義す る. 典型的な再生率の 100 時刻毎の変遷は Fig. 9 のよ らになり，800 時刻で約 95\% に達した.この時点で節 数は 145 となり, レベル数は 6 ないし 17 に分布してい た. また再生率の代わりの評価量として, 過去 100 時刻 にわたり提案経路により衝突の可能性ありといら䇾告が 発生する頻度を調べたところ，800 時刻で約 1\% で減 少した. 日常の運用環境では障害物は実験のときほど多 くないから,この数值は更に小さくなる.

ところで障害物回避移動の問題解決に当っては，次の 二つの側面を意識する必要がある ${ }^{19)}$ :

1. 複雑な障害物配置状況において，ほとんど選択余 地のない唯一の移動経路を見出すこと；

2. 日常的な障害物配置状況において, 幾通りもの移 動経路の中から適切な一つを選ぶこと。

前者を解決するには論理的な移動計画が有効であるが, 後者は直観的応答に属する処理要因を多く含んでいる. さて工学の通常の方法論では, 障害物回避移動問題は, あるコスト評価規範の下での論理的な最適経路生成問題 へ㷌着させるのが普通であるが，そのとき採用したコス 卜評価規範があらゆる意味での適切さを反映しているわ けではないから，しばしば不自然な移動経路を生成する 結果となる.これに対し提案した方法を用いると，人工

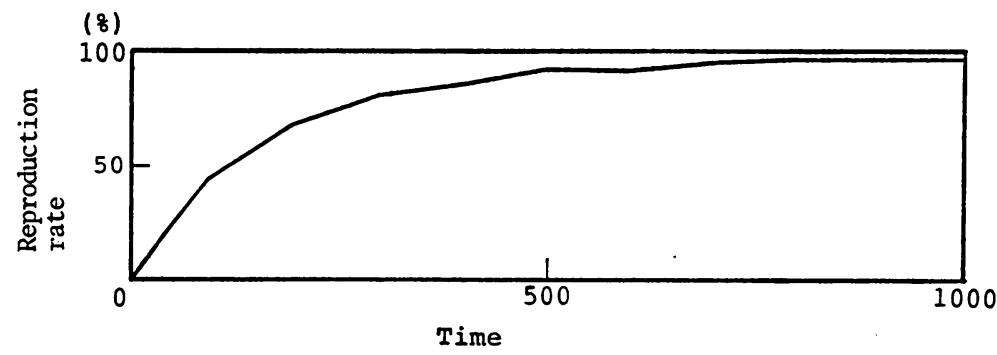

Fig. 9 Efficiency of learning for obstacle avoiding movement
れる.このとき論理的な経路生成規則は，任意のカメラ 画像と移動経路とを関連付けている意味で, データベー スの圧縮された表現形態と見なせる．従ってアルゴリズ ム Aは, 論理的手法による経路生成の业みを, 外部から 獲得した知識に応じて逐次修正していると解釈でき,2.2 節で述べた図式下で障害物回避移動問題が自然な形で解 決されていることがわかる。

\section{4 上位制御について}

上位制御プログラムに関しては，制御指令をC言語の オプション命令群として処理できるインターブリターを 作成し，ロボットの行動計画が沉用的に記述できるよう

配虑した．本論文の目的は計算機言語の質を専門的に検 討することではないから，ここではロボットの移動計画 を汎用的に記述し得る最小規模の言語を示す．だが以下 の様式に従い,より繊細な命令群を備えるロボット言語 を開発し得ることは明らかであろう．このようにロボッ トをハードウェアからソフトウェアに至るまで系統立て て設計することは, 将来ロボットに高度の知能を賦与し 最大限の能力を発揮させるための基礎として重要である.

さて，変数〔姿勢角〕は 0 から 359 までの整数値をと り，壁面に対するロボットの相対姿勢を表わす．変数 〔現ブロック〕は $Y$ 内の值をとり，ロボットが居るブロ ック番号を表わす. 変数 [目標方位]は \{北, 東, 南, 西）のいずれかの值をとり，ロボットが進行すべき方位 を表わす。ロボット言語は，これらを引数とする四つの 命令を有する. 命令 RobInit は上 記三つの変数を引数とし，これら によって指定された状態にロボッ トを待機させる. 命令 RobEnd は引数を持たず，ロボットを制御 から解放する．命令 RobTurn は 〔姿勢角〕および〔目標方位〕を 引数とし，口ボットを後者によっ て指定された方位へ向ける. 命令 RobMove は三つの変数を引数と 
し〔目標方位〕側の隣接するブロックへ到達するまでロ ボットを前進させる.

ロボット言語は二つのエラーメッセージを備える、第 一のエラーメッセージ

“Detected syntax error in (行番号)!”

は，ニーザーテキスト中に文法誤りが含まれている旨を 知らせる、第二のエラーメッセージ

"Impossible to advance in (行番号)!"

は, データベースから再生された移動経路により衝突の 危険があるか，または，障害物が多過ぎるためカメラの 視角内でもはや障害物回避経路が見出せない旨を知らせ る.

インタープリターは, 四つのサブルーチンと主プログ ラムとから成る、サブルーチン“位置同定”は〔現ブロ ックコを引数とし, カメラを制御しつつ, 3.2 節で学習 したデータベースを用いて風景から位置を同定し, 結果 を引数に入れて復帰する. サブルーチン“障害物回避移 動” は[资勢角]と[エラー番号]とを引数に持ち， 3.3 節 のデータベースより再生した移動経路に従って障害物回 避移動を一回行ならと同時に, 〔姿勢角〕を更新する; だが，もし衝突の危険があるか移動経路が見出せない場 合には, 〔エラー番号〕に第二のエラーメッセージを表 示するよう指示値を代入し復㷌する，サブルーチン “姿 勢角補整” は[姿勢角]を引数とし, もし床と壁面之の 境界線が完全な直線として検出されたとき（即ち, 境界 線を乱す障害物がないとき)，まず[姿勢角]に基づいて 頭部カメラを壁面に垂直になるよう向けた後, 床と壁面 との境界線注目してカメラの向きの誤差を算出し, 最

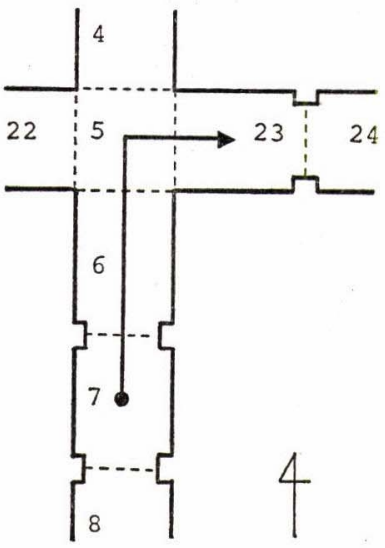

Fig. 10 An example of motion planning

後に誤差に応じて〔姿勢角〕の值を修正する，サブルー チン“姿勢制御” は三つの変数を引数とし，ロボットを 〔目標方位〕に向ける一方，〔姿勢角〕を更新する.

主プログラムはニーザーテキストから文章を一行読み 取り，次のいずれかを実行する：

・も乙命令が RobInit であるときロボットを待機状 態にし，RobEnd であるときロボットを制御から解放す る;

・もし命令が RobTurn であるときサブルーチン“姿 勢制御”を実行する;

-もし命令が RobMove であるとき，目標方位】に ある隣接ブロックに到達するまで（即ち[現ブロック] が，この隣接ブロックの番号を示すに至るまで)， サブ ルーチン “姿勢制御”, “障害物 回避移動”, 姿勢角補
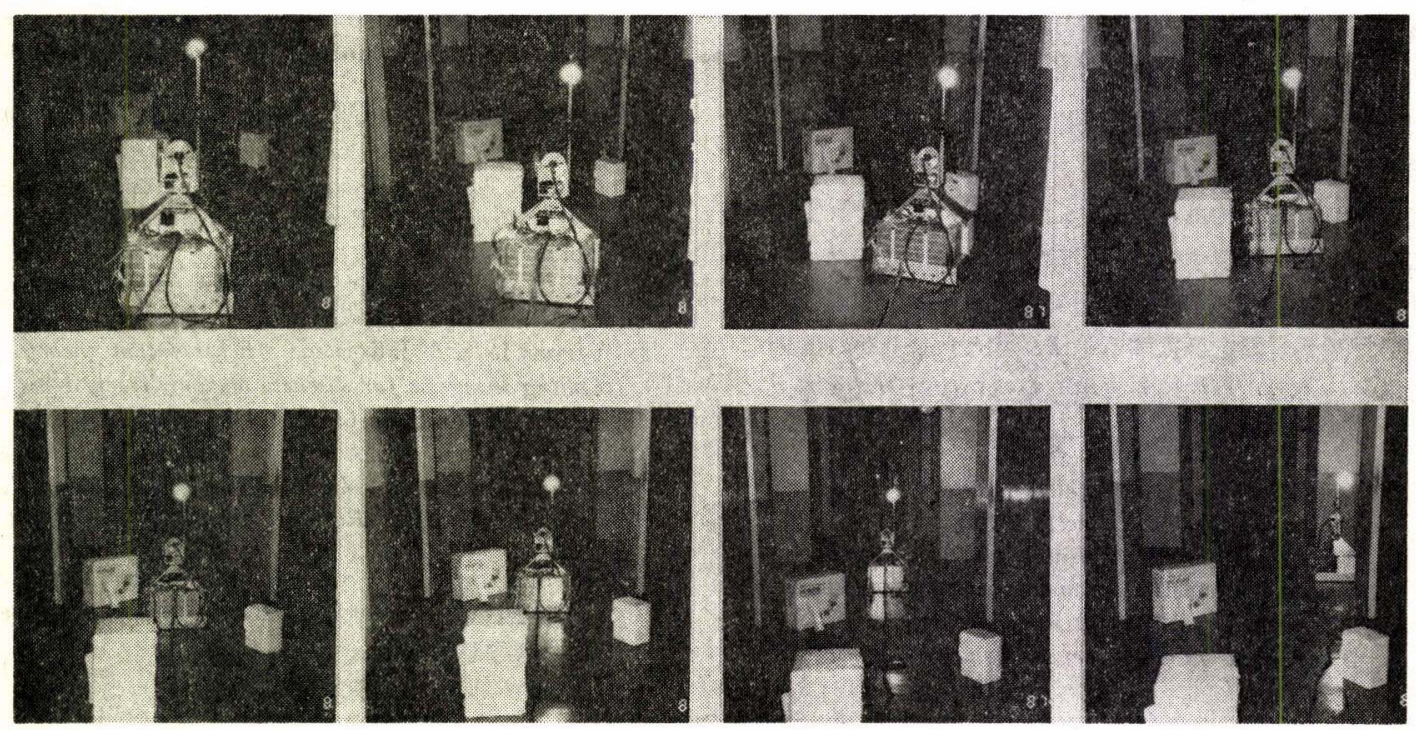

Fig. 11 Actual behavior of robot 
整”、“位置同定”をこの順序で繰り返す；

-もし文章がいずれの命令でもなければ，第一のエラ ーメッセージを表示しロボットを待機状態におく.

以上において，もし“障害物回避移動” の際に〔エラー 番号了が第二のエラーメッセージの指示値を受け取った ならば,このメッセージを表示しロボットを待機状態に おく.そうでなければ後続行の処理に䔟る.

例えば，次のような上位制御プログラム：

int 姿勢角 $=0$, 現ブロック=7;

RobInit（姿勢角，現ブロック，北）;

RobTurn (姿勢角，北）；

RobMove（姿勢角，現ブロック，北）;

RobMove（姿勢角，現ブロック，北）;

RobMove（姿勢角，現ブロック，東）;

RobEnd ;

に対し、ロボットは Fig. 10 および Fig. 11 のような行 動をとる. ここに, こま毎の時間経過は約 $40 \mathrm{sec}$ に相当 する.

\section{4. むす ひ}

連想データベースを自己組織化する学習機構を提案し， カメラ方式自律移動ロボットへ応用した.この学習機構 は, 予め学習用のモデルが与えられている方式と異なっ て, 環境から供給される情報に応して記憶構造を自己組 織化してゆくことにより, 要求された任意の入出力応答 を学習する. 本論文では, 提案した方法が自律移動口ボ ットへ有効であることを示したが，その他にも文字認識 への応用も試みている20). 特に, 似た入力信号の集合に おける局所構造はわかっているが, 複雑な全体構造を容 易には見出せない場合，本方法は威力を発揮する.

提案した自己組織化アルゴリズムAの一つの欠点は， データベース組織化の計算時間の上界が, 学習対象の複 雑さ $\mathrm{r}$ の増大のある部分クラスに対してのみしか保証さ れていないことであるが (2.3 節参照), 今後これをより 広いクラスへ扗張することが課題である. そのためには $\mathrm{d}$ の值を直接用いた連想規則でなく，その分布関数に基 ついた連想規則を導入する手法が考えられるが，詳細に ついては実際への応用を考虑しながら検討中である.

\section{考文献}

1) 辻 三郎, “知識処理とロボティックス”, 人工知能学会 誌, pp. 30-37, Vol 1, No. 1, 1986

2) Tsumura, T. et al., "Position and Heading Compasations for a Self-Contained Measuring System of a Vehicle Travelling on Roadway", Japan U.S.A. Symposium on Flexible Automation, pp.353-359,
1985

3) Jarvis, R. A. and J. C. Byrne, "An Automated Guided Vehicle with Map Building and Path Finding", 4 th Int. Symp. of Robotics Research, pp. 155-162, 1987

4) Walter, S. A., “The Sonar Ring : Obstacle Detection for a Mobile Robot", 1987 IEEE Int. Conf. on Robotics \& Automation, pp. 1574-1579, 1987

5) Goto, Y. and A.Stentz, "The CMU system for mobile robot navigation", 1987 IEEE Int. Conf. on Robotics \& Automation, pp.99-105, 1987

6) Madarasz, R. et al., "The design of an autonomous vehicle for the disabled", IEEE Jour. of Robotics \& Automation, Vol. RA-2, No.3, pp.117-125, 1986

7) Brooks, R. A. et al., "Self calibration of motion and stereo vision for mobile robots", 4-th Int. Symp. of Robotics Research, pp. 267-276, 1987

8) Triendl, E. and D. J. Kriegman, "Stereo vision and navigation within buildings", 1987 IEEE Ins. Conf. on Robotics \& Automation, pp. 1725-1730, 1987

9) Bhatt, R. et al., "A Real-Time Guidance System for an Autonomous Vehicle", 1987 IEEE Int. Conf. on Robotics \& Automation, pp. 1785-1791, 1987

10) Montgomery, M. et al., "Navigation Algorithm for a Nested Hierarchical System of Robot Path Palnning among Polyhedral Obstacles", 1987 IEEE Int. Conf. on Robotics \& Automation, pp. 1616-1622, 1987

11) Winston, P. H., “Learning structural descriptions from examples ${ }$, The Psycology of Computer Vision, McGraw-Hill, 1975

12) Lenat, D. B., “AM: An artificial intelligence approach to discovery in mathematics as heuristic search, "Knowledge-Based System in Artificial Intelligence, Mc Graw-Hill, 1979

13) Rumelhart, D.E. et al., "Learning representations by back-propagating errors," Nature, Vol 323, pp. 533-536, 1986

14) Hopfield, J. J. and D. W. Tank, "Computing with neural circuit: A model", Science, Vol 233, pp. 625-633, 1986

15) “特集ニューラル・ネット”, 数理科学, 7, サイエンス 社, 1987

16) Goldfarb, L., "A new approach to pattern recognition", Progress in Pattern Recognition 2, NorthHolland, 1985

17) Martin, J., Computer Data-Base Organization, Prentice-Hall Inc., 1977

18) Csiszar, I. and J. Korner, "Information theory : Coding theorems for discrete memoryless systems", Academic Press, pp. 61-85, 1981

19) Arimoto, S. et al., "A Feasible Approach to Automatic Planning of Collision-Free Robot Motions", 4 th Int. Symp. of Robotics Research, pp. 163-172, 1987

20）鈴木 寿, 有本 卓, “ニニバーサル学習機械と 英活字 認識への応用”, 電子情報通信学会誌, 分冊A（1987 年 10 月以降掲載予定） 
鈴木 寿 (Hisashi SUZUKI)

昭 58 阪大·基碟工・生物工卒, 同年, 同大学院進学, 現在に至る. 情報理論, 機 械知能の研究に従事. 工修.

（日本ロボット学会学生会員）

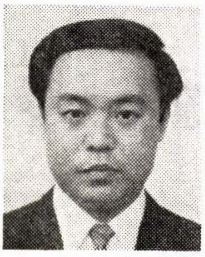

大西弘之 (Hiroyuki ONISHI)

昭 60 グローリー工業入社, 現在に至る. 自律移動車の研究に従事. 現在は監視用知 能ロボットを開発中,

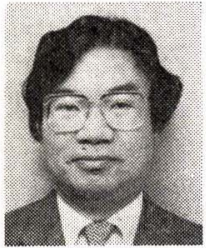

有本 卓 (Suguru ARIMOTO) 昭 34 京大・理卒. 昭 34 沖電気工業入 社, 電子計算機開発に從事. 昭 37 東大· 工・助手, 昭 42 同講師, 昭 43 阪大·基 礎工・助教授, 昭 48 同教授となり現在に 至る.この間, 情報理論, ディジタル信号 処理, 制御理論の研究飞従事. 1984 年 IEEE 情報理論最優秀論文賞受賞. 現在はロボットの知能化に 興味を持つ. 工博. IEEE Fellow.

（日本ロポット学会正会員）

\title{
Self-Organization of Associative Data-Base and Application to Autonomous Mobile Intelligent Robot*
}

\author{
Hisashi SUZUKI** Hiroyuki ONISHI*** Suguru ARIMOTO**
}

\begin{abstract}
A simple and efficient method of self-organizing associative data-bases is proposed with a demonstration of application to an autonomous mobile intelligent robot. The system consists of a processing block prescribed and a memory block being blank at the initial state. For a current input signal, the processing block searches for a past input signal that is similar to the current one in the memory block, and recalls the referred information. If the information accompanied with the current input signal does not agree with the recalled one, the new information is added to a data-base in the memory block, with influence reflects on the processing at the next time. Thus, the data-base grows dependently on its states and input signals in a self-organizing way. Since carrier of the data-base organization depends on the series of inputs, each data-base acquires an individual structure. If an input series of sufficient length is given, the relation between input signals and the referred information tends to agree with that of the input series. This system is meaningful in the sense that it gives a conceptual but essential model of intuitive information processing in human's brain and, from a practical viewpoint, in the sense that this system is applicable to a learning mechanism that learns universally any input-output response desired. A camera-type autonomous mobile robot for indoor passages utilizing this learning mechanism is introduced. The brain of robot is constructed on a microcomputer of processor i 80286, and behavior of the robot is controlled with a small-size robot language that is supplemented to C-language. A successful experiment result is shown.
\end{abstract}

Key words : Self-organization, associative data-base, learning, autonomous mobile robot, camera.

\footnotetext{
* Received June 1 st, 1987

** Faculty of Engineering Science, Osaka University

*** Glory Industrial Co., Ltd.
} 